\title{
Digestion of uncrushed leaf tissues by leaf-snipping larval Lepidoptera
}

\author{
R.V. Barbehenn* \\ University of California, Department of Entomological Sciences, Berkeley, CA 94720, USA \\ Received April 29, 1991 / Accepted in revised form September 3, 1991
}

Summary. Cynodon dactylon (Poaceae) leaf pieces recovered from the frass of final-instar Paratrytone melane larvae (Lepidoptera: Hesperiidae) were composed of 14-22 percent crushed cells and 78-86 percent uncrushed cells, yet approximate digestibilities of soluble carbohydrates and protein averaged 78 and 88 percent, respectively. Therefore, nutrients from uncrushed cells were extracted by $P$. melane. The ability of $P$. melane and another leaf-snipping lepidopteran, Pseudaletia unipuncta (Noctuidae), to digest the contents of uncrushed bundle sheath and mesophyll cells in $C$. dactylon was examined with transmission electron microscopy. Organelles and plasma membranes were digested in the foreguts and midguts of both species. These findings suggest that nutrients in uncrushed leaf cells may be extracted through plasmodesmata and cell wall pores after membranes are digested. The generality of leaf-snipping, vis-a-vis leaf crushing, among larval Lepidoptera was assessed by surveying the mandible morphologies of 202 species. In 82 percent of the species surveyed only incisor regions were present. I conclude that leaf-snipping is a common mode of feeding among phytophagous Lepidoptera and that the digestion of cell contents is efficient despite the fact that few of the cells of ingested plant tissues are crushed.

Key words: Lepidoptera - Digestion - Larvae - Mandible $-\mathrm{C}_{4}$ grasses

Chewing leaf tissues in order to liberate nutrients from the crushed cells is generally viewed as a necessary prerequisite to digestion in phytophagous insects (e.g., Cockfield 1988; Dow 1986). The role of the molar-bearing mandibles in Acrididae (Orthoptera) in crushing leaf tissues during ingestion has been well studied (Caswell and Reed 1975, 1976; Bennack 1981; Boys 1981). The

* Current address: Department of Biology University of Michigan Ann Arbor, MI 48109-1048, USA relationship between mandible morphology and damage to ingested leaf tissues has received little attention in Lepidoptera, however. Many lepidopteran larvae ingest leaf tissues after a minimal amount of chewing (i.e., tissue crushing) and appear to have a different digestive strategy from the Orthoptera. Tropical Saturniidae, for instance, have toothless mandibles and ingest relatively large leaf pieces (Bernays and Janzen 1988). Bernays and Janzen (1988) suggested that only cells at the crushed edges of such large leaf pieces were digested. This conclusion follows a view which prevails despite evidence from studies of digestion in lepidopteran larvae that (1) uncrushed cells in leaf tissues become largely empty following digestion (Biederman 1919; Rybicki 1957; Harvey 1975) and (2) nutrient digestion efficiencies are greater than expected based on the small percentage of cells which are crushed (Evans 1939; Hocking and Depner 1964).

The ability to digest the cell contents of uncrushed cells would appear to be of primary importance for leaf-snipping Lepidoptera since they are not known to produce cellulases (Chapman 1982) and the physical damage done to some cells during ingestion would not be expected to affect the ultrastructure of uncrushed cells (Valle et al. 1989). Nutrients in leaves, such as proteins and soluble carbohydrates, are largely contained in chloroplasts and plasma membranes (Chapin et al. 1987; Farrar and Farrar 1986) and therefore may not diffuse from cells until their membranes are disrupted. Previous observations of the digestion of intact leaf cell contents have been made with light microscopy and thus have not recorded changes in cell ultrastructure.

This study addresses several questions regarding the existence of a leaf-snipping digestive strategy among certain Lepidoptera. What percentage of ingested leaf cells are crushed during ingestion and passage through the gut? Do nutrient approximate digestibilities exceed expected values based on the percentage of cells crushed, suggesting that nutrients from uncrushed cells are available to the insect? What ultrastructural changes occur in uncrushed cells that might allow nutrients to be extracted 
in the insect gut? In particular, are membranes digested sufficiently early in the passage of leaf pieces through the gut for nutrients to be extracted? Finally, what percentage of lepidopteran larvae possess mandibles bearing only incisors and, thus, how common among lepidopteran species is the ingestion of snipped, vis-a-vis crushed, leaf tissues?

The anatomy of $\mathrm{C}_{4}$ grasses makes them particularly useful for examining the problem of digesting uncrushed leaf cells in insects. The bundle sheath cells (BSCs) of $\mathrm{C}_{4}$ grasses are believed to be indigestible by phytophagous insects because their thick lignified cell walls resist crushing (Berry et al. 1970; Caswell et al. 1973; Caswell and Reed 1975, 1976; Heidorn and Joern 1984). In addition, the BSCs contain a large percentage of the nutrients of $\mathrm{C}_{4}$ grasses, since only they and the mesophyll cells (MCs) are photosynthetically active (Bjorkman and Berry 1973; Caswell et al. 1973; $\mathrm{Ku}$ et al. 1979). Using the $\mathrm{C}_{4}$ grass Cynodon dactylon (L.) Pers. (Poaceae), I studied damage to the ultrastructure of uncrushed BSCs and MCs as they passed through the guts of two graminivorous Lepidoptera with leaf-snipping mandibles, Paratrytone melane Edwards (Hesperiidae) and Pseudaletia unipuncta (Haworth) (Noctuidae).

\section{Material and methods}

\section{Bite size and leaf tissue damage}

$P$. melane larvae were reared on $C$. dactylon in screen cages $(30 \times 30 \times 75 \mathrm{~cm})$ in natural light at a mean temperature of $28^{\circ} \mathrm{C}$ (range $=24-32^{\circ} \mathrm{C}$ ). $P$. umipuncta larvae were reared on seedling Triticum aestivum L. (Poaceae) and maintained in an insectary with a light:dark cycle of $16 \mathrm{~h}: 8 \mathrm{~h}$ at $25^{\circ} \mathrm{C}$. Bite sizes in fourth- and fifth-instar $P$. melane were measured in frass collected from four larvae reared on $C$. dactylon. Bites $(n=14-18$ per larva in each instar) were magnified and their perimeters traced using a Zeiss dissecting microscope with a camera lucida. The areas of the enlarged outlines were measured using a video image digitizer (Bioscan).

General observations of leaf pieces (bites) dissected from guts and in frass peilets from late-instar larvae of $P$. melane $(n=14)$ and $P$. unipuncta $(n=22)$ were made with dissecting and compound microscopes. The percent of cells crushed during ingestion was estimated from $C$. dactylon in frass pellets from one larva during its fourth and fifth instars. Ten leaf pieces were chosen at random from each instar. Due to the uniformity of grass leaf anatomy, BSCs were used as indicators of overall amounts of tissue damage. Numbers of BSCs crushed at each point along a vascular bundie were estimated to range from one to two, based on preliminary observations of leaf tissue damage. Lengths of vascular bundles cut through during ingestion were measured in each leaf piece and multiplied by the mean number of BSCs/mm. BSCs at the ends of vasculat bundles were also assumed to be crushed during ingestion. Total numbers of BSCs per bite were calculated from the average number of BSCs $/ \mathrm{mm}^{2}$ multiplied by the areas of bites. Percentages of BSCs crushed per bite were then calculated from the numbers of BSCs crushed divided by the total number of BSCs per bite.

\section{Digestion time}

Digestion time was defined as the time from ingestion of $C$. dactylon to the time it was found in the hindguts of dissected larvae. Final (fifth)-instar P. melane larvae were placed on potted Ehrharta erecta
Lam. (Poaceae; $\mathrm{C}_{3}$ ) in a reverse-photoperiod room ( $14 \mathrm{~h}$ light: $10 \mathrm{~h}$ dark) at $25^{\circ} \mathrm{C}$ for nine days with fresh $E$. erecta supplied daily. This pre-treatment accustomed these strictly nocturnal larvae to conditions that facilitated observations of their feeding during the day. Larvae $(n=10)$ were placed individually in clear plastic boxes $(20 \times 10 \times 3 \mathrm{~cm})$, each with a vial of E. erecta leaves in water. Larvae were observed under red light during the dark period. They were allowed to feed for one meal, following which $E$. erecta was replaced with $C$. dactylon, After taking a meal on C. dactylon, E. erecta was replaced. All feeding times were recorded. $C$. dactylon bites were easily distinguished from $E$. erecta in dissected larvae. Larvae were dissected after $2 \mathrm{~h}, 8.5 \mathrm{~h}, 9 \mathrm{~h}, 20 \mathrm{~h}, 21 \mathrm{~h}(n=2)$, and $23 \mathrm{~h}$ from the time they ingested $C$. dactylon. Six dissected $P$. melane larvae contained $C$. dactylon in their hindguts.

Similar experiments were performed using final (sixth)- instar $P$. unipuncta larvae $(n=10$ and 12$)$. Larvae were placed individually in petri dishes at $28^{\circ} \mathrm{C}(16 \mathrm{~h}$ light: $8 \mathrm{~h}$ dark $)$ and allowed to feed overnight on seedling $T$. aestivum in vials of water. Larvae were allowed to feed on $C$. dactylon for one meal, following which $T$. aestivum was replaced. All feeding times were recorded. $P$. unipuncta were dissected after $15 \mathrm{~min}(n=2), 30 \mathrm{~min}, 1 \mathrm{~h}, 1.5 \mathrm{~h}$, $2.5 \mathrm{~h}(n=3), 3 \mathrm{~h}(n=6), 3.5 \mathrm{~h}$, and $4 \mathrm{~h}$. Eight $P$. unipuncta larvae were dissected with $C$. dactylon in their hindguts. P. unipuncta were also observed during a 24 -h period in a separate experiment to establish their diurnal and nocturnal feeding pattern. C. dactylon is a common host plant of $P$. melane (Brown 1984) and is an acceptable host plant of $P$. unipuncta (pers. obs.).

\section{Digestion of leaf cell ultrastructure}

In two experiments $P$. melane or $P$. unipuncta larvae which were used for measuring digestion times were placed on ice for approximately five min, following which $C$. dactylon leaf pieces were rapidly dissected and fixed in $0.05 \mathrm{M}$ Sorenson's phosphate buffer with $4 \%$ glutaraldehyde ( $\mathrm{pH}$ 7.2). Digestion time for each leaf tissue sample was determined as the difference between the times of ingestion and fixation. Leaf tissue samples were examined from the foreguts of one $P$. melane larva and three $P$. unipuncta larvae, from the midguts of three $P$. melane larvae and three $P$. unipuncta larvae, and from the hindguts of four $P$. melane larvae and one $P$. unipuncta larva. C. dactylon leaves from plants previously used as food for each larva were cut into approximately $1 \mathrm{~mm}^{2}$ pieces with a razor blade and fixed. These samples served as controls for ultrastructural artifacts.

All C. dactylon samples were stored overnight at $6^{\circ} \mathrm{C}$ in Sorenson's phosphate buffer, post-fixed with $1 \% \mathrm{OsO}_{4}$, dehydrated in a graded ethanol series and propylene oxide, and embedded in Araldite resin. Araldite blocks were trimmed to expose tissue in the center of each leaf piece for sectioning. Thus, only cells without physical damage from ingestion by larvae were observed. Thin (gold) sections were made with Sorvall MT-2 and MT-6000 ultramicrotomes and stained with uranyl acetate and Reynold's lead citrate. Sections were observed with Zeiss 109 or JEOL JEM 100CX transmission electron microscopes (TEM). Sections from a single C. dactylon leaf piece were observed from each larva. A total of 50-60 BSCs were examined from each species (5-10 BSCs per sample). A larger, undetermined number of MCs adjacent to BSCs were also observed. Measurements of the diameters of plasmodesmata $(n=14)$ from the walls of three BSCs were made from electron micrographs.

\section{Nutrient digestibility}

Approximate digestibilities of soluble carbohydrates and protein were measured in fourth- and fifth-instar $P$. melane larvae in separate experiments. Newly-molted, fourth-instar larvae $(n=14)$ were taken from a colony (fall generation) reared in a greenhouse on $C$. dactylon. In order to measure ingestion and egestion, larvae were placed in individual containers in an incubator with a light: 
dark cycle of $14 \mathrm{~h}: 10 \mathrm{~h}$ and corresponding temperatures of $30^{\circ} \mathrm{C}$ : $20^{\circ} \mathrm{C}$. Larvae were fed daily with weighed amounts of $\mathrm{C}$. dactylon leaves placed in vials of water. Aliquots of $C$. dactylon leaves, for measuring percent dry weight and nutrient content, uneaten food, and frass were collected daily, dried at $70^{\circ} \mathrm{C}$, and weighed to the nearest $0.1 \mathrm{mg}$. Newly-molted, fifth-instar larvae $(n=15)$ were taken from a colony (summer generation) reared on $C$. dactylon in ambient lab conditions (mean temperature $=28^{\circ} \mathrm{C}$ ). This experiment was performed as described above with the exception that a light: dark cycle of $12 \mathrm{~h}: 12 \mathrm{~h}$ was used.

The approximate digestibilities of soluble carbohydrates and protein were calculated on a dry weight basis as (mg nutrient ingested-mg nutrient egested)/(mg nutrient ingested) $* 100$. Nutrient levels were analyzed in samples of $C$. dactylon leaves and $P$. melane frass after grinding them to 40 or 60 mesh in a Wiley mill. Soluble carbohydrates were measured using the anthrone method on aqueous extracts (Yemm and Willis 1954). Sucrose was used as a standard. Measurements were made on leaf samples from 13 dates and 14 fourth instar frass samples and, with fifth-instar larvae, on leaf samples from 11 dates and frass samples pooled from six dates. With fourth-instar $P$. melane, protein was measured as total amino acids with ninhydrin in hydrolyzed leaf samples ( $n=4$ dates) and individual frass samples $(n=8)$. Protein hydrolysis was carried out in $6 \mathrm{M} \mathrm{HCl}$ at $110^{\circ} \mathrm{C}$ for $24 \mathrm{~h}$ in screw-cap vials (Pierce) flushed with nitrogen. Hydrolyzed bovine serum albumin was used as a standard. Averages of two replicates were used for calculating percent protein. With fifth-instar larvae, protein $(\% \mathrm{~N} \times 5.3)$ was measured by Kjeldahl (Tecator) in leaf samples ( $n=11$ dates) and frass samples pooled from six dates.

\section{Mandible morphology}

1 examined the mandible morphologies of late-instar larvae of 37 species from 10 families of Lepidoptera: 21 species of Hesperiidae (Barbehenn 1989), Junonia coenia Hubner, Euphydrias chalcedona Doubleday and Hew., Agraulis vanillae (L.) (Nymphalidae), Harissina americana (Guerin) (Zygaenidae), Uresiphita reversalis (Guenee) (Pyralidae), Bombyx mori (L.) (Bombycidae), Malacosoma californicum (Packard) (Lasiocampidae), Manduca sexta (L.) (Sphingidae), Phryganidia californica Packard (Dioptidae), Lymantria dispar (L.) and Orgyia leucostigma (J.E. Smith) (Lymantriidae), and Trichoplusia ni (Hubner), P. unipuncta, Heliothis zea (Boddie), Agrotis orthogonia Morrison and Spodoptera eridania (Cram.) (Noctuidae). One to three specimens of each species were examined using a dissecting microscope. The mandibles of 165 additional species were surveyed based on illustrations in two catalogs of larval insects (Peterson 1951; Stehr 1987). Scanning electron micrographs were made with an ISI DS-130 scanning electron microscope on platinum-coated mandibles of fourth- and fifth-instar $P$. melane larvae.

\section{Results}

Bite size and leaf tissue damage

Frass pellets from $P$. melane and $P$. unipuncta larvae were conglomerates of large rectangular or lense-shaped pieces of leaves. Bites observed with light microscopy from dissected guts and in frass pellets from each species contained crushed cells bordering the cut edges but were otherwise uncrushed. $71-80 \%$ of the leaf cells ingested by fourth-instar $P$. melane were uncrushed and $78-86 \%$ of those ingested by fifth-instar larvae were uncrushed (Table 1). Bite size in P. melane increased by $74 \%$ from the fourth to the fifth instar (Table 1).
Table 1. Bite size (mean $\pm S E$ ), leaf tissue damage, and nutrient approximate digestibilities (AD) from Cynodon dactylon ingested by Paratrytone melane larvae. Ranges of percentages of cells crushed per bite were estimated using the percentage of damaged bundle sheath cells as an index

\begin{tabular}{lllll}
\hline Instar & $\begin{array}{l}\text { Bite Size } \\
\left(\mathrm{mm}^{2}\right)\end{array}$ & $\begin{array}{l}\text { Percentage of } \\
\text { cells crushed } \\
\text { per bite }\end{array}$ & $\begin{array}{l}\text { Soluble } \\
\text { carbohydrate } \\
\text { AD (\%) }\end{array}$ & $\begin{array}{l}\text { Protein } \\
\text { AD (\%) }\end{array}$ \\
\hline 4 & $0.073 \pm 0.003^{*}$ & $20-29$ & $67.8 \pm 4.2$ & $45.7 \pm 3.6$ \\
5 & $0.127 \pm 0.004$ & $14-22$ & $78.0^{\mathrm{a}}$ & 79.7 \\
\hline
\end{tabular}

* $P<0.001$ (Mann-Whitney $U$-test)

${ }^{a}$ Fifth-instar soluble carbohydrate and protein ADs based on pooled frass sampies

\section{Digestion time}

The rate of passage of leaf pieces through the guts of $P$. melane and $P$. unipuncta differed greatly, according to the feeding pattern of each species. $P$. melane had an average digestion time of $17.8 \mathrm{~h}$ (range $=8.5-23 \mathrm{~h}, n=6$ ). By contrast, $P$. unipuncta fed both diurnally and nocturnally and had an average digestion time of $2.9 \mathrm{~h}$ (range $=2.5-3.2 \mathrm{~h}, n=8$ ).

\section{Digestion of leaf cell ultrastructure}

The ultrastructure of $C$. dactylon control samples was undamaged by sample preparation (Fig. 1A). Cell walls were not visibly damaged by digestion in any samples observed from either $P$. melane or $P$. unipuncta. Plasmodesmata through cell walls measured $61.2 \pm 8.0 \mathrm{~nm}$ (mean $\pm \mathrm{SE}, n=14$ ) in diameter.

In $P$. melane, none of the uncrushed cells observed in bites sampled from foreguts, midguts, or hindguts contained intact ultrastructure. Chloroplasts and cell membranes were found in a digested state as in Fig. 1C after two hours, the earliest digestion time observed. Enlarged plastoglobuli, probably composed of membrane components, were the most visible remnants of cell contents (Fig. 1C). Extensive digestion of cell membranes therefore occurred in $P$. melane within at least one-ninth of the average total digestion time.

In $P$. unipuncta, earlier stages of digestion of cell ultrastructure were observed. BSCs in leaf samples that had been digested for $15 \min (n=2)$ contained chloroplasts which were either undamaged or were swollen and contained disorganized thylakoid membranes. After $30 \mathrm{~min}$, BSCs were filled with disorganized and disrupted chloroplasts (Fig. 1B; $n=1$ ). In leaf samples digested for over $30 \mathrm{~min}(n=4)$, ultrastructural damage had progressed to a similar state as observed in $P$. melane in all uncrushed cells observed ( $n=$ approximately 30 BSCs) (Fig. 1D). Digestion of cell membranes therefore occurred in $P$. unipuncta before one sixth of the average total digestion time. 

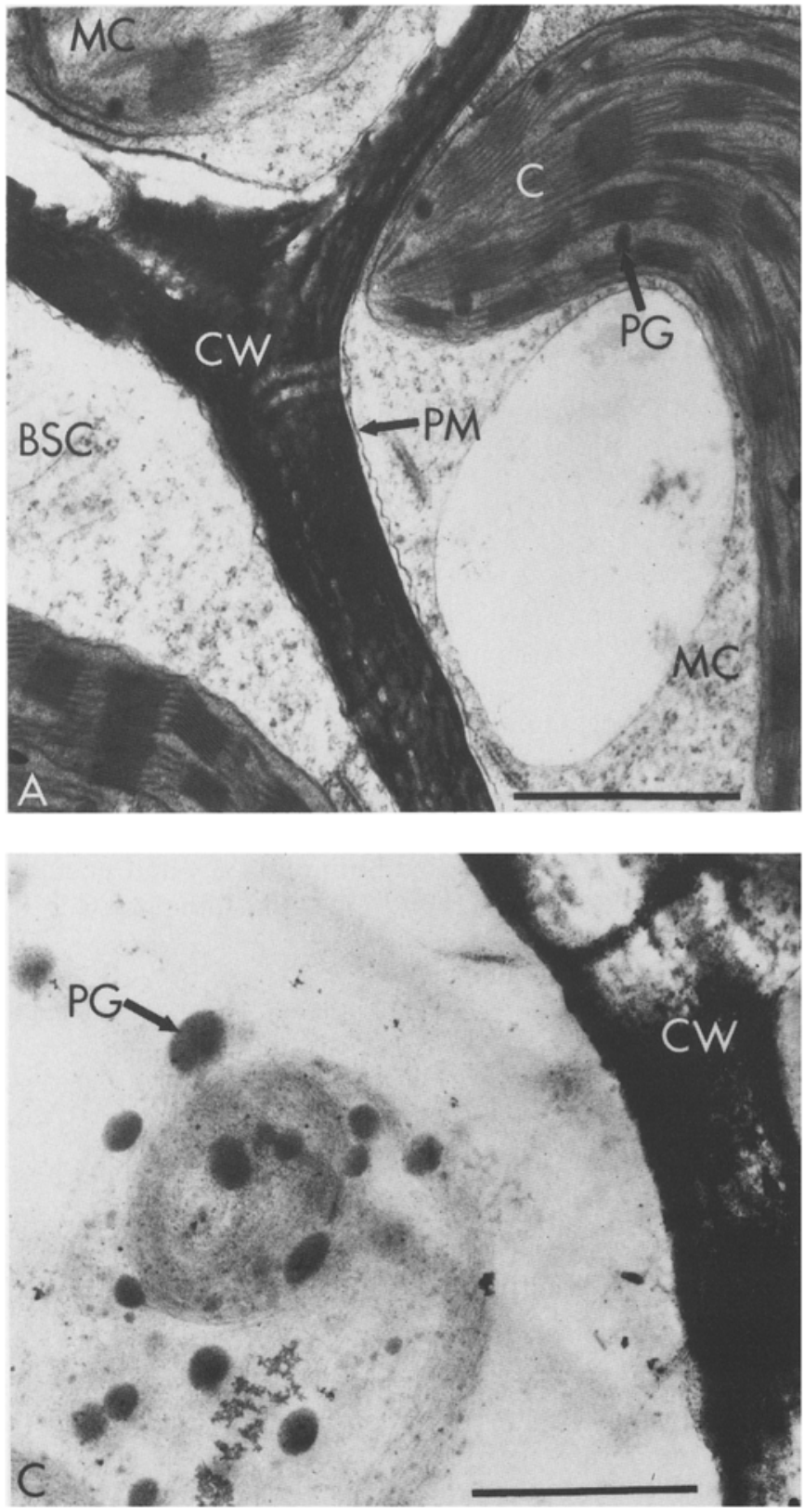

Fig. 1A-D. Representative examples of the digestion of bundle sheath cell $(B S C)$ ultrastructure in $C$. dactylon leaves by two species of lepidopteran larvae. (A) Intact ultrastructure representative of BSCs and mesophyll cells $(M C)$ in control samples. (B) Two BSCs containing disorganized chloroplast and thylakoid membranes 30 min after ingestion by $P$. unipuncta (representative of one larva). (C) Enlarged plastoglobuli and other undigested BSC contents 21

\section{Nutrient digestibility}

Approximate digestibilities of soluble carbohydrates and protein greatly exceeded the amounts expected if only crushed leaf cells were digested (Table 1). Digestibility of soluble carbohydrates ranged from 2.3-3.4 times greater than expected in fourth-instar larvae and from 3.5-5.6 times greater in fifth-instar larvae, relative to the percentage of cells crushed. Similarly, protein digestibilities were 1.6-3.4 times greater than expected in fourth-instar lar-
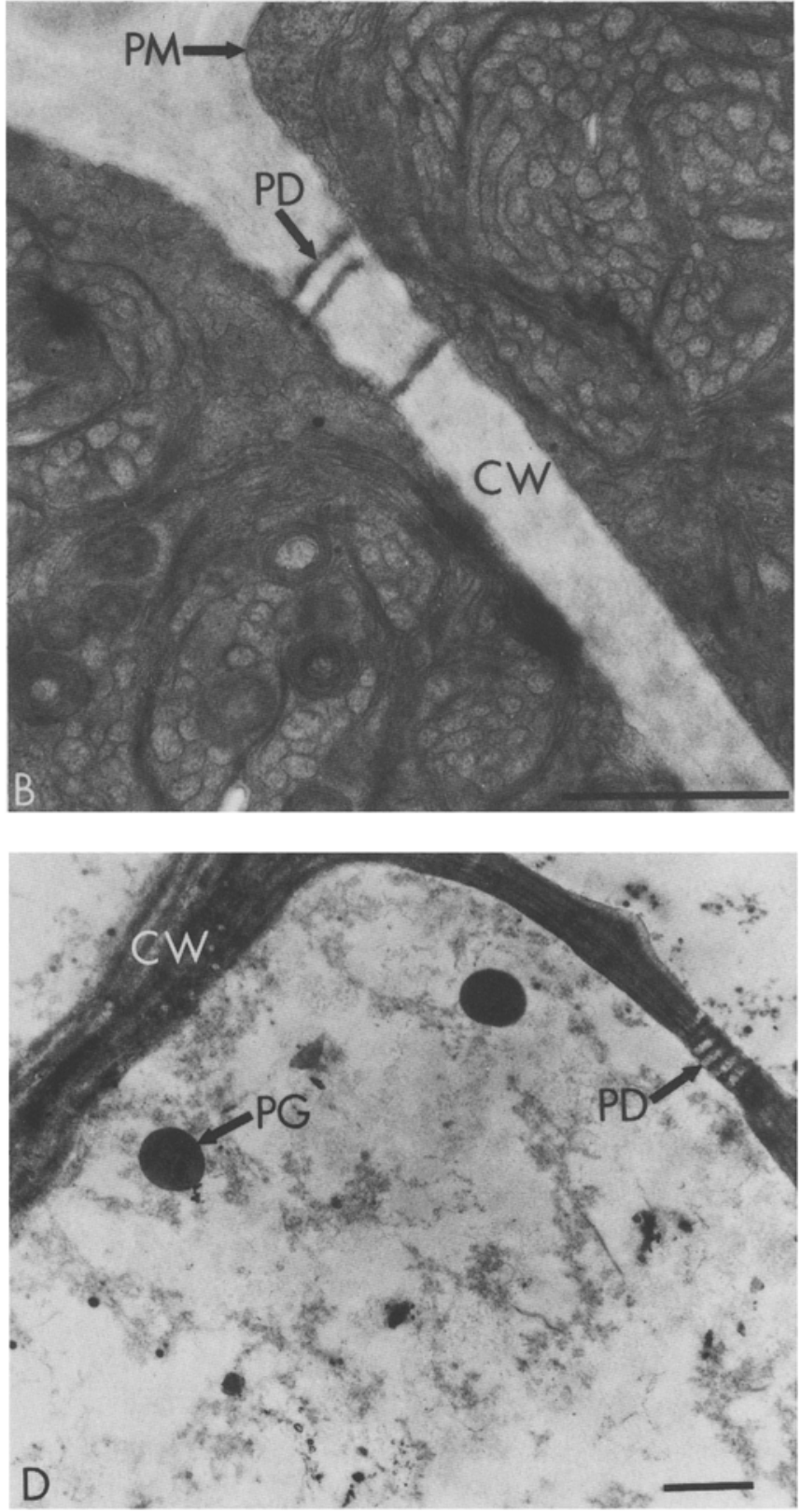

h after ingestion by $P$. melane (representative of all samples observed from $P$. melane). (D) Enlarged plastoglobuli in a BSC three $h$ after ingestion by $P$. unipuncta. Digested cells lacked plasma membranes and intact organelles and were largely empty. Bars $=1 \mathrm{mi}-$ cron. $C=$ chloroplast, $P M=$ plasma membrane, $C W=$ cell wall, $P D=$ plasmodesma, $P G=$ plastoglobule

vae and 3.6-5.7 times greater than expected in fifth-instar larvae. Differences in protein digestibilities between instars may have resulted from differences in the methods used for their measurement in each experiment.

\section{Mandible morphology}

Of the 202 species of Lepidoptera surveyed, none had a molar region (as found in Orthoptera) and $82 \%$ had only 


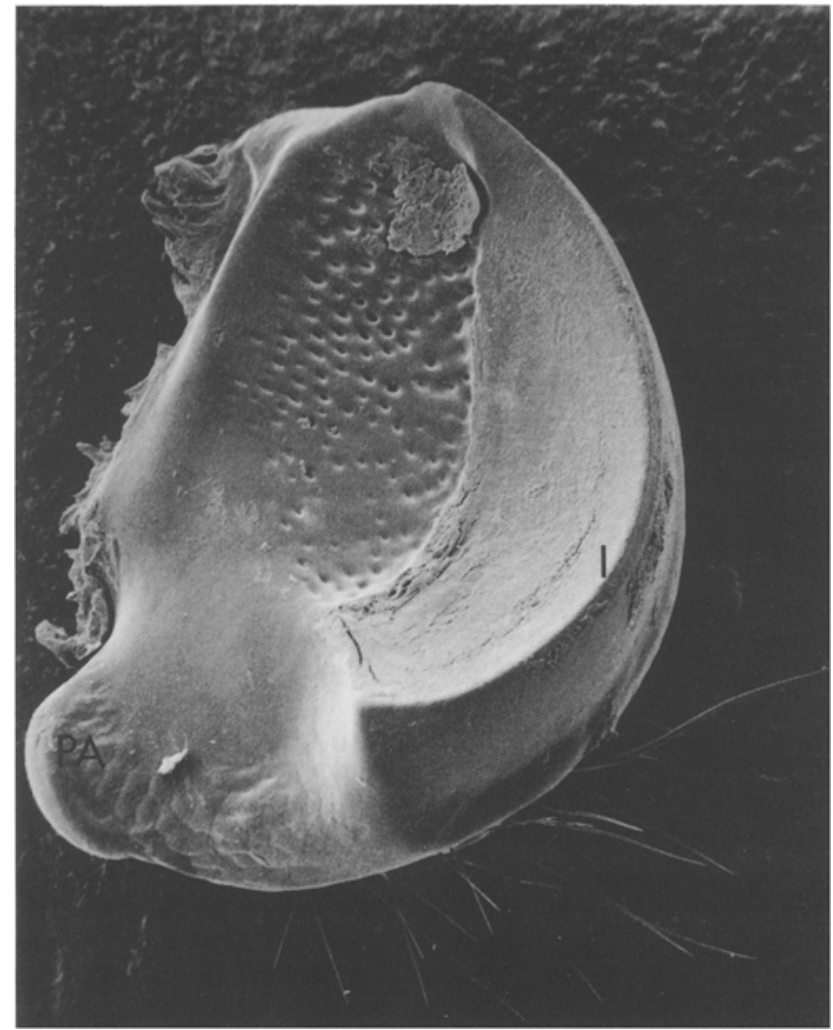

Fig. 2. Left mandible of a fourth-instar $P$. melane larva showing inner, anterior view of incisor region. The absence of a molar region is typical of Lepidoptera. Setae are present on the ventral surface (lower right). $\mathrm{PA}=$ posterior articulation, $\mathrm{I}=$ incisor region. Magnification $=104 \times$

an incisor region. $12.5 \%$ of the species had one or more non-incisor teeth or ridges (e.g., O. leucostigma and L. dispar). An additional 5.5\% had mandibles bearing a retinaculum (Peterson 1951). Wide variation between species in the morphology of the incisor region was found; $P$. melane and $P$. unipuncta possessed a knife-like incisor region (Fig. 2), whereas most other species possessed a serrate incisor region.

\section{Discussion}

This study shows that lepidopteran larvae are able to digest and efficiently extract the contents of uncrushed leaf cells. Ultrastructural changes in uncrushed BSCs and $\mathrm{MCs}$ in the $\mathrm{C}_{4}$ grass $C$. dactylon showed a similar pattern of digestion by final-instar $P$. melane and $P$. unipuncta larvae. In some cases digestion began in the foregut. In all cases in which the effects of digestion were observed after $30 \mathrm{~min}, 0 \%$ of the plasma membranes and organelles remained intact.

The rapid digestion of the membranes of uncrushed cells appears to allow nutrient extraction to occur with surprisingly high efficiency. Digestibility of soluble carbohydrates and protein in final and penultimate instar $P$. melane larvae was much greater than that possible if only nutrients from crushed cells were available. The relatively high nutrient digestion efficiencies of other leaf-snipping Lepidoptera suggest that these species are also able to digest uncrushed leaf cells efficiently (Evans 1939; Horie et al. 1985).

\section{Mechanisms of digestion and extraction of uncrushed leaf cells}

The digestion of uncrushed cells has been considered to result from plant autolytic enzyme activity (Rybicki 1957; Hocking and Depner 1961; Vonk and Western 1984). However, in the only direct examination of the enzymes ingested in leaf tissues, Santos, et al. (1983) found no significant activity in cassava leaves ingested by Erinnyis ello (Sphingidae).

A second possible mechanism of digestion is the diffusion of insect digestive enzymes, and/or other gut factors, into uncrushed leaf cells. If insect phospholipases diffuse into uncrushed leaf cells they may play an important role in membrane disruption. For instance, when vacuolar membranes are damaged and their contents released into the cytoplasm, chloroplasts and other plastids may rupture explosively in a matter of seconds (O'Brien and McCully 1981). The high efficiencies of phospholipid digestion in $B$. mori (78-91\%), a leaf-snipping species (pers. obs.), further suggests intracellular phospholipase activity (Horie et al. 1985). Surfactants, created during phospholipid digestion (Martin and Martin 1984), may also be important in disrupting membranes and/or increasing their permeabilities (Thomson and Moeller 1983). An alkaline $\mathrm{pH}$ similar to the midguts of lepidopteran larvae had little effect on leaf cell contents in vitro (Rybicki 1957).

The results of the TEM study of plant cell digestion show that once plasma and organelle membranes are digested, the cell wall becomes the major barrier between the insect gut lumen and leaf cell contents. The most visible paths by which nutrients and enzymes may diffuse accross intact cell walls are plasmodesmata. These form numerous and relatively large channels through cell walls, with average diameters ranging from 61 to $91 \mathrm{~nm}$ (Robards 1976; Evert et al. 1977; this study). By comparison, lepidopteran digestive enzymes have diameters averaging only $6.7 \mathrm{~nm}$ (range $=3.9-8.6 \mathrm{~nm})($ Santos and Terra 1986). Desmotubule membranes, which may greatly reduce the diameters of plasmodesmata (Terry and Robards 1987; Valle et al. 1989), are unlikely to remain intact given the efficiency of digestion of other membranes in uncrushed cells. Once nutrients enter intercellular spaces, which are continuous from the BSCs to the stomates (Evert et al. 1977), their diffusion may continue unimpeded into the gut lumen either through stomates or the crushed edges of leaf pieces.

In addition, nutrients and small enzymes may diffuse directly through cell walls. Pores in cell walls may be as large as 3.5-8.6 $\mathrm{nm}$ in diameter (Carpita et al. 1979; Baron-Epel et al. 1988). The largest of these pores allowed trans-wall equilibria for proteins with 5.0 and 7.2 $\mathrm{nm}$ diameters to be established in 15 and $45 \mathrm{~min}$, respectively (Baron-Epel et al. 1988). Such rates of protein 
diffusion through cell walls suggests that some insect enzymes could penetrate cell walls through large pores sufficiently rapidly to account for the rates of digestion of cell ultrastructure observed in $P$. unipuncta. Following membrane digestion, cell walls may thus be quite permeable to nutrients such as amino acids (approx. $0.5 \mathrm{~nm}$ diameter), mono- and disaccharides $(0.7-1.0 \mathrm{~nm}$ diameter), and globular proteins (4-8 $\mathrm{nm}$ diameter) (Freifelder 1987). Large oligomeric proteins, such as the photosynthetic enzyme RuBisCo (13.2 nm diameter) (Chapman et al. 1987), may dissociate at the high pHs found in many lepidopteran midguts (Rintamaki 1989), possibly allowing them to diffuse accross cell walls more readily. It is interesting to note that protein extraction from leaf tissues increased markedly at alkaline $\mathrm{pHs}$ (Jones et al. 1989); this may be a major benefit of maintaining high gut $\mathrm{pH}$ (Schultz and Lechowicz 1986).

\section{Lepidopteran vs. orthopteran digestive strategies}

The generality of a digestive strategy based on leaf-snipping among other phytophagous Lepidoptera is supported by the high percentage of these species that have mandibles bearing only a simple incisor region. Although incisor-bearing mandibles are used by early-instars of some species of Lepidoptera to skeletonize leaves, and may conceivably be used by later instars to make small bites, the available evidence shows a consistent relationship between mandible morphology and leaf tissue damage: mandibles with only an incisor region snip largely uncrushed leaf pieces ( $n=17$ species) (Hocking and Depner 1961; Bernays and Janzen 1988; this study).

A digestive strategy of extracting nutrients from largely uncrushed leaf tissues in a high $\mathrm{pH}$ gut (Berenbaum 1980) contrasts with that of Orthoptera, such as acridids. Acridids use molar-bearing mandibles to shear apart and crush leaf tissues, digesting liberated cell contents in a relatively neutral pH gut (Wigglesworth 1972). Digestive efficiencies of Lepidoptera and Orthoptera fed T. aes tivum $\left(\mathrm{C}_{3}\right)$ were comparable, however, suggesting that a strategy of tissue crushing is not necessarily superior to leaf-snipping; the mean $\mathrm{AD}$ (based on total dry mass) of four noctuid species with simple incisor-bearing mandibles was $50.8 \%$ (range $=32-59 \%$ ), whereas eight acridid species had a mean $\mathrm{AD}$ of $44.2 \%$ (range $=34-65 \%$ ) (Bernays and Barbehenn 1987). A comparison between acridids, in which BSC contents remained undigested (Caswell and Reed 1975, 1976), and two lepidoptera in this study, in which no BSC contents remained undigested, suggests that the ability to digest uncrushed leaf tissues may actually benefit leaf-snipping species that feed on $\mathrm{C}_{4}$ plants. Further work is needed on the mechanisms allowing leaf-snipping Lepidoptera to digest and extract the cell contents of uncrushed leaf tissues.

Acknowledgements. I thank Pat Akers, Elizabeth Bernays, Rex Dadd, Jeremy Lee, Michael M. Martin, and Clytia Montllor for comments on the manuscript, Carolyn Schooley and Doug Davis for assistance with TEM, Jorge Santiago-Blay for taking the SEM pictures, David Bay for help with photography, and Don MacNeill for loaning most of the hesperiid larvae examined. TEM and SEM work was done at the Robert D. Ogg Electron Microscopy Laboratory at the University of California, Berkeley. This work was supported by NSF doctoral dissertation improvement grant no. BSR-8701000, a Sigma Xi grant-in-aid of research, and NSF grant no. BSR-8904043 to Michael M. Martin.

\section{References}

Barbehenn R (1989) The nutritional ecology and mechanisms of digestion of $\mathrm{C}_{3}$ and $\mathrm{C}_{4}$ grass-feeding Lepidoptera. $\mathrm{PhD}$ thesis, University of California, Berkeley

Baron-Epel O, Gharyal PK, Schindler M (1988) Pectins as mediators of wall porosity in soybean cells. Planta 175:389-395

Bennack DE (1981) The effects of mandible morphology and photosynthetic pathway on selective herbivory in grasshoppers. Oecologia $51: 281-283$

Berenbaum M (1980) Adaptive significance of midgut $\mathrm{pH}$ in larval lepidoptera. Am Nat 115:138-146

Bernays EA, Barbehenn RV (1987) Nutritional ecology of grass foliage-chewing insects. In: Slansky F Jr., Rodriguez JG (eds) Nutritional ecology of insects, mites, spiders, and related invertebrates. John Wiley and Sons, New York, pp 147-176

Bernays EA, Janzen DH (1988) Saturniid and sphingid caterpillars: two ways to eat leaves. Ecology $69: 1153-1160$

Berry JA, Downton WJS, Tregunna EB (1970) The photosynthetic carbon metabolism of Zea mays and Gomphrena globosa: the location of $\mathrm{CO}_{2}$ fixation and the carboxyl transfer reactions. Can J Bot 48:777-786

Biedermann W (1919) Beiträge zur vergleichenden Physiologie der Verdauung. Arch ges Physiol 174:392-425

Bjorkman O, Berry J (1973) High-efficiency photosynthesis. Sci Am $229: 80-93$

Boys M (1981) Food selection by some graminivorous Acrididae. PhD thesis, University of Oxford, U.K.

Brown JW (1984) Host records for Paratrytone melane (Edwards) (Hesperiidae). J Lep Soc 38:138

Carpita N, Sabularse D, Montezinos D, Delmer DP (1979) Determination of the pore size of cell walls of living plant cells. Science 205: 1144-1147

Caswell M, Reed FC (1975) Indigestibility of $\mathrm{C}_{4}$ bundle sheath cells by the grasshopper, Melanoplus confusus. Ann Entomol Soc Am $68: 686-688$

Caswell H, Reed FC (1976) Plant-herbivore interactions: the indigestibility of $\mathrm{C}_{4}$ bundle sheath cells by grasshoppers. Occologia $26: 151-156$

Caswell H, Reed F, Stephenson SN, Werner PA (1973) Photosynthetic pathways and selective herbivory: a hypothesis. Am Nat 107: 465-480

Chapin FS III, Bloom AJ, Field CB, Waring RH (1987) Plant responses to multiple environmental factors. BioScience $37: 49-57$

Chapman RF (1982) The insects: structure and function, Harvard University Press, Cambridge

Chapman MS, Suh SW, Cascio D, Smith WW, Eisenberg D (1987) Sliding-layer conformational change limited by the quaternary structure of plant RuBisCO. Nature 329:354-356

Cockfield SD (1988) Relative availability of nitrogen in host plants of invertebrate herbivores: three possible nutritional and physiological definitions. Oecologia 77:91-94

Dow JAT (1986) Insect midgut function. Adv Insect Physiol $19: 187-328$

Evans AC (1939) The utilization of food by the larvae of the buff-tip Phalera bucephala (Linn.) (Lepidopt.) Proc Royal Entomol Soc (London) 14:25-30

Evert RF, Eschrich W, Heyser W (1977) Distribution and structure of the plasmodesmata in mesophyll and bundle sheath cells of Zea mays L. planta 136:77-89 
Farrar SC, Farrar JF (1986) Compartmentation and fluxes of sucrose in intact leaf blades of barley. New Phytol 103:645-657

Freifelder D (1987) Molecular biology. Jones and Bartlett Publishers, Inc., Boston

Harvey GT (1975) Nutritional studies of eastern spruce budworm (Lepidoptera: Tortricidae) II. Starches. Can Entomol 107:717-728

Heidorn T, Joern A (1984) Differential herbivory on $\mathrm{C}_{3}$ versus $\mathrm{C}_{4}$ grasses by the grasshopper Ageneotetix deorum (Orthoptera: Acrididae). Oecologia 65:19-25

Hocking B, Depner KR (1961) Larval nutrition in Agrotis orthogonia (Lepidoptera: Phalaenidae): digestive enzymes. Ann Entomol Soc Am 54:86-98

Horie Y, Nakasone S, Watanabe K, Nakamura M, Suda H (1985) Daily ingestion and utilization of various kinds of nutrients by the silkworm, Bombyx mori (Lepidoptera: Bombycidae). Appl Entomol Zool 20:159-172

Jones CG, Hare JD, Compton SJ (1989) Measuring plant protein with the Bradford assay. I. Evaluation and standard method. J Chem Ecol 15:979-992

Ku SB, Schmitt MR, Edwards GE (1979) Quantitative determination of RuBP carboxylase-oxygenase in leaves of several $C_{3}$ and $\mathrm{C}_{4}$ plants. J Exp Bot 30:89-98

Martin MM, Martin JS (1984) Surfactants: their role in preventing the precipitation of protein by tannins in insect guts. Oecologia $61: 342-345$

O'Brien TP, McCully ME (1981) The study of plant structure: principles and selected methods. Termarcarphi Pty Ltd., Melbourne

Peterson A (1951) Larvae of insects. Part 1: Lepidoptera and plant infesting Hymenoptera. Edwards Bros., Ann Arbor

Rintamaki E (1989) Formation of disulphide cross-linked aggregates of large subunit from higher plant ribulose-1,5-bisphosphate carboxylase-oxygenase. J Exp Bot 40:1305-1313

Robards AW (1976) Plasmodesmata in higher plants. In: Gunning
BES, Robards AW (eds) Intercellular communication in plants: studies on plasmodesmata. Springer-Verlag, New York, pp 15-57

Rybicki M (1957) Mechanism of digestion of leaves of green plants by some lepidopterous caterpiliars. Acta Biol Exp (Warsaw) $17: 289-316$

Santos CD, Ferreira C, Terra WR (1983) Consumption of food and spatial organization of digestion in the cassava hornworm, Erinnyis ello. J Insect Physiol 29:707-714

Santos CD, Terra WR (1986) Distribution and characterization of oligomeric digestive enzymes from Erinnyis ello larvae and inferences concerning secretory mechanisms and the permeability of the peritrophic membrane. Insect Biochem 16:691-700

Schultz JC, Lechowicz MJ (1986) Hostplant, larval age, and feeding behavior influence midgut $\mathrm{pH}$ in the gypsy moth (Lymantria dispar). Oecologia $71: 133-137$

Stehr FW (1987) Immature insects. Kendall/Hunt Publishing Co., Dubuque, Iowa

Terry BR, Robards AW (1987) Hydrodynamic radius alone governs the mobility of molecules through plasmodesmata. Planta 171: 145-157

Thomson WW, Moeller CH (1983) Effects of TWEEN-20, polyoxyethylene sorbitan monolaurate on the ultrastructure and organization of chloroplast membranes. Protoplasma 114:173-178

Valle EM, Craig S, Hatch MD, Heldt HW (1989) Permeability and ultrastructure of bundle sheath cells isolated from $\mathrm{C}_{4}$ plants: structure-function studies and the role of plasmodesmata. Botanica Acta 102:276-282

Vonk HJ, Western JRH (1984) Comparative biochemistry and physiology of enzymatic digestion. Academic Press, New York

Wigglesworth VB (1972) The principles of insect physiology. Methuen and Co., London

Yemm EW and Willis AJ (1954) The estimation of carbohydrates in plant extracts by anthrone. Biochem $\mathbf{J} 57: 508-514$ 